\title{
ANALISIS KERAGAAN GENETIK JAGUNG TOLERAN CEKAMAN KEKERINGAN DI LAHAN SAWAH TADAH HUJAN
}

\section{(Analysis Of Genetic Performance Of Drought Tolerant Maize In Rainfed Low Land)}

\author{
Eko Ilmawan $^{1)}$; St. Subaedah ${ }^{2)}$ dan A.Takdir ${ }^{3)}$ \\ ${ }^{1)}$ Mahasiswa Magister Agroteknologi PPs-UMI, Makassar \\ E-mail : eko_sp80@yahoo.co.id \\ ${ }^{2)}$ Jurusan Agroteknologi Fakultas Pertanian, UMI \\ ${ }^{3)}$ Balai Penelitian Tanaman Serealia, Maros
}

\begin{abstract}
This study aims to evaluate the genetic performance of 8 corn genotypes that are tolerant of drought stress. The study was conducted at the Experimental Garden, Bajeng, Gowa Regency, South Sulawesi. The research was carried out using a Split Plot Design method. As the main plot is a water stress treatment consisting of no stress, moderate stress and severe stress. As a subplot is a prospective hybrid corn genotype consisting of 8 genotypes and two comparative varieties namely Bima 3 and Bima 7. The results of this study indicate that Genotype G7 is the highest genotype for plants, Genotypes G2 and G5 are genotypes with, silking interval anthesis (ASI) the smallest and fastest harvesting age. The G3 genotype is the genotype with the longest root.
\end{abstract}

Keywords : performance, maize, genotype, tolerant, and drought stress

PENDAHULUAN

Peningkatan produksi tanaman jagung dapat ditempuh melalui usaha intensifikasi dan ekstensifikasi. Usaha ektensifikasi dapat dilakukan dengan pemanfaatan lahan tadah hujan setelah panen padi (Mulyani et al.,2001). Pengembangan tanaman jagung di lahan sawah tadah hujan setelah penanaman padi harus ditunjang oleh teknik budidaya yang tepat karena penanaman jagung di lahan sawah tadah hujan umumnya dilakukan pada musim kemarau dengan kondisi curah hujan yang terbatas (Sutoro et al.,1988).
Kendala utama pengembangan tanaman jagung pada musim kemarau adalah ketersediaan air tanah yang terbatas (Subaedah, 2018), akibatnya tanaman yang tumbuh pada kondisi ini dapat mengalami defisit air sehingga sulit memberikan hasil sesuai dengan potensi yang dimilikinya. Hal ini dapat terjadi karena defisit air selain berpengaruh secara langsung terhadap berbagai proses fisiologis dalam tanaman, juga mengurangi kemampuan tanaman dalam menyerap unsur hara. Kekeringan mempengaruhi respon fisiologis, biokimia dan molekuler yang mengatur 
pertumbuhan dan produktivitas tanaman (Shukla, Awasthi, Rawat, dan Kumar, 2012). Lahan yang mengalami cekaman kekeringan akan menyebabkan aerasi dalam tanah terganggu dan pasokan oksigen dalam tanah tidak lancar, sehingga perkembangan tanaman menjadi kerdil. Air diperlukan tanaman untuk memenuhi kebutuhan biologisnya, antara lain untuk memenuhi transpirasi pada proses asimilasi untuk pembentukan karbohidrat serta pengangkutan fotosintat ke seluruh jaringan tanaman.

Tanaman jagung merupakan salah satu tanaman yang sangat sensitif terhadap kekeringan dan kahat hara (Subaedah, et al., 2014). Levitt (1980) stress kekeringan pada tanaman disebabkan oleh dua hal yaitu: (1) kekurangan suplai air di daerah perakaran, (2) permintaan air yang berlebihan oleh daun dimana laju evapotranspirasi melebihi laju absorbsi air oleh akar tanaman, walaupun keadaan air tanah cukup. Faktor yang pertama banyak dialami oleh tanaman yang ditanam pada lahan-lahan kering marginal.

Salah satu upaya untuk meningkatkan produksi jagung di lahan sawah tadah hujan setelah panen padi yaitu pemilihan varietas jagung yang toleran kekeringan. Saat ini varietas jagung yang toleran terhadap cekaman kekeringan jumlahnya masih sangat terbatas, sehingga perlu upaya untuk mencari varietas lain yang toleran terhadap cekaman kekeringan melalui seleksi genotipe jagung yang toleran terhadap cekaman kekeringan.

Terdapat galur yang menunjukkan ketahanan tertinggi pada kondisi cekaman kekeringan berat dan sedang terhadap kandungan nitrogen $(\mathrm{N})$ berdasarkan produksi mutlak dan relatif serta nilai heritabilitas tergolong tinggi (Aisyah, 2014).

Hasil penelitian Darnis (2015) menunjukkan bahwa dalam seleksi dan karakterisasi jagung calon hibrida tolerant cekaman kekeringan diperoleh genotipe jagung dengan jumlah produksi tertinggi 10,2 ton ha ${ }^{-1}$ pada kondisi tercekam serta diperoleh 2 genotipe yang memberikan rata-rata tinggi tanaman yang lebih tinggi, umur berbunga jantan dan betina yang lebih cepat dan anthesis silking interval (ASI) paling rendah. Sementara Wahditiya (2016) melaporkan bahwa analisis gabungan antar lingkungan menunjukkan bahwa terdapat 3 genotipe dengan kategori sangat toleran kekeringan, 111 genotipe dengan kategori toleran moderat kekeringan, dan 116 
genotipe dengan kategori peka genotipe jagung yang diuji terhadap (berdasarkan nilai stress tolerance index cekaman kekeringan serta menganalisis yang diuji pada lingkungan yang berbeda). indeks sensitivitas kekeringan dari Genotipe pembentuk hibrida yang terpilih genotipe jagung yang diuji terhadap merupakan genotipe yang dinilai potensial digunakan untuk pengembangan jagung toleran cekaman kekeringan

Berdasarkan hal ini maka salah satu cara untuk mengatasi kendala cekaman kekeringan di lahan sawah tadah hujan adalah menggunakan varietas jagung yang toleran terhadap cekaman kekeringan. Varietas unggul sangat berperan dalam upaya meningkatkan produktivitas jagung, baik dalam hasil per satuan luas maupun sebagai komponen pengendali hama dan penyakit. Sifat tanaman juga dipertimbangkan dalam merakit varietas jagung unggul, beberapa faktor antara lain kesesuaian dengan kondisi lingkungan (tanah, iklim) dan referensi petani terhadap sifat lainnya yaitu umur, warna, ukuran, dan rendemen biji serta sifat brangkasan tetap hijau pada saat panen tongkol (masak fisiologis) menjadi bagian penting dalam menghasilkan suatu varietas jagung unggul yang tahan terhadap cekaman kekeringan.

Penelitian ini bertujuan untuk mengevaluasi keragaan genetik dari cekaman kekeringan.

\section{BAHAN DAN METODE}

Penelitian ini dilakukan dalam bentuk percobaan di lahan sawah tadah hujan setelah panen padi pada musim kemarau yang berlokasi di Kebun Percobaan Bajeng (Bajeng Experimental Station), Balai Penelitian Tanaman Serelia - Badan Penelitian dan Pengembangan Pertanian - Kementerian Pertanian Republik Indonesia, Kecamatan Bajeng, Kabupaten Gowa, Provinsi Sulawesi Selatan. Daerah tersebut terletak pada ketinggian $55 \mathrm{~m}$ di atas permukaan laut (dpl) dengan kemiringan lahan $<3 \%$, dan tingkat kesuburan tanah rendah sampai sedang.

Bahan yang digunakan dalam penelitian ini berasal dari benih jagung calon hibrida beberapa genotype antara lain : G1, G2, G3, G4, G5, G6, G7 dan G8 dan 2 varietas pembanding yang berumur genjah yaitu Bima 3 dan Bima 7 . Penelitian ini dilaksanakan dengan menggunakan metode rancangan petak terbagi (Split plot Design). Sebagai petak 
utama adalah perlakuan cekaman yang perlakuan pemberian air (pengairan) terdiri dari 3 taraf yaitu C0 : tanpa sekali dalam 10 hari sehingga cekaman (pengairan dilakukan secara ketersediaan air untuk proses fisiologis optimal yaitu sekali dalam 10 hari). C1: terpenuhi. Selain itu faktor genetik dari cekaman sedang (pengairan dihentikan genotipe/varietas pembanding juga sangat pada saat tanaman berumur 35 sampai 65 mempengaruhi periode pertumbuhan dari hari setelah tanam). C2 : cekaman parah (pengairan dihentikan setelah tanaman berumur 35 hari setelah tanam sampai panen). Sebagai anak petak adalah genotipe-genotipe jagung calon hibrida dan 2 varietas pembanding yaitu Bima 3 dan Bima 7. Setiap kombinasi perlakuan diulang sebanyak tiga kali sebagai kelompok sehingga diperoleh 90 unit percobaan. Adapun parameter yang diamati meliputi tinggi tanaman, anthesis silking interval (ASI), umur panen dan panjang akar.

\section{HASIL DAN PEMBAHASAN}

\section{Tinggi Tanaman}

Hasil analisis statistik terhadap variabel tinggi tanaman menunjukkan bahwa interaksi antara perlakuan cekaman dan perbedaan genotipe memberikan pengaruh yang sangat nyata terhadap tinggi tanaman jagung.

Genotipe G7 Optimal memberikan rata-rata tinggi tanaman jagung tertinggi $(275,53 \mathrm{~cm})$. Hal ini disebabkan karena tanaman jagung, sehingga dengan adanya perbedaan perlakuan pemberian air (pengairan) yaitu Cekaman Sedang dan Cekaman Parah serta adanya perbedaan atau keragaman secara genetik dari genotipe jagung menyebabkan pengaruh terhadap tinggi tanaman jagung.

Menurut Aqil et al, (2007), bahwa ketepatan pemberian air sesuai dengan tingkat pertumbuhan tanaman jagung sangat berpengaruh terhadap produksi. Periode pertumbuhan tanaman yang membutuhkan adanya pengairan dibagi menjadi lima fase, yaitu fase pertumbuhan awal (selama 15-25 hari), fase vegetatif (25-40 hari).

Menurut Makmur (1993); Azizian (2014); Henry (2013); Jatoi et al, (2014) dalam Wahditiya (2016), bahwa cekaman kekeringan tanaman jagung yang terjadi mulai pada fase pembungaan bunga sampai fase pematangan biji akan menurunkan pertumbuhan tinggi tanaman, rendemen, bobot seribu biji, serta hasil jagung per hektar. Pengaruh nyata atau 
sangat nyata dari genotipe ini diduga cekaman kekeringan dapat mengurangi disebabkan adanya perbedaan atau atau menekan pertumbuhan tinggi keragaman secara genetik dari genotipe tanaman. jagung yang diuji. Cekaman air atau

Tabel 1. Rata-rata Tinggi Tanaman Jagung $(\mathrm{cm}) 8$ Genotipe dan 2 Varietas Pembanding pada Kondisi Perlakuan Optimal, Cekaman Sedang dan Cekaman Parah, 8 MST.

\begin{tabular}{clll}
\hline \multirow{2}{*}{ Genotipe/Varietas } & \multicolumn{3}{c}{ Perlakuan } \\
\cline { 2 - 4 } & Optimal & Cekaman Sedang & Cekaman Parah \\
\hline G1 & $266.27 \mathrm{ab}$ & $231.80 \mathrm{a}$ & $229.00 \mathrm{a}$ \\
G2 & $203.00 \mathrm{ab}$ & $199.73 \mathrm{~b}$ & $200.00 \mathrm{~b}$ \\
G3 & $263.53 \mathrm{ab}$ & $229.80 \mathrm{a}$ & $228.33 \mathrm{a}$ \\
G4 & 252.07 & $209.60 \mathrm{~b}$ & 212.60 \\
G5 & 220.20 & 219.20 & $198.60 \mathrm{~b}$ \\
G6 & 240.00 & 225.73 & $222.33 \mathrm{a}$ \\
G7 & $275.53 \mathrm{ab}$ & $248.00 \mathrm{ab}$ & $249.67 \mathrm{ab}$ \\
G8 & $270.80 \mathrm{ab}$ & $251.27 \mathrm{ab}$ & $245.00 \mathrm{ab}$ \\
BIMA 3 & 241.67 & 213.07 & 203.27 \\
BIMA 7 & 247.13 & 225.00 & 219.67 \\
\hline \hline
\end{tabular}

NP.BNT taraf $0.05=13.42$

Keterangan : Nilai rata-rata pada kolom yang sama yang diikuti oleh huruf $(a, b)$ berarti berbeda nyata dengan varietas Bima 3, huruf b berbeda nyata dengan varietas Bima 7 berdasarkan uji BNT taraf 0.05 .

Teguh Wijayanto et al., (2014) pada umur 42 hst, perlakuan cekaman kekeringan hanya berpengaruh sangat nyata terhadap tinggi tanaman, tetapi berpengaruh tidak nyata terhadap diameter batang dan jumlah daun. Hal ini mungkin disebabkan karena pertumbuhan (jumlah) daun dan diameter batang tanaman jagung lebih dikontrol oleh faktor genetik dari pada faktor lingkungan.

\section{Anthesis Silking Interval (ASI)}

Berdasarkan hasil analisis statistik menunjukkan bahwa interaksi antara perlakuan cekaman dan perbedaan genotipe berpengaruh sangat nyata terhadap variabel Antesis Silking Interval (ASI). Hasil uji lanjutan menunjukkan bahwa Antesis Silking Interval (ASI) pada Tabel 2 tercepat terdapat pada genotipe G2 Cekaman Sedang dan G5 Cekaman Sedang dan Cekaman Parah yaitu 1,00 hari dibanding genotipe G1, G3, G4, G6, G7 dan G8.

\section{Umur Panen}

Berdasarkan hasil analisis statistik menunjukkan bahwa interaksi antara perlakuan cekaman dan perbedaan genotipe berpengaruh sangat nyata 
terhadap umur panen dari beberapa tercepat terdapat pada genotipe G2 dan genotipe jagung calon hibrida. Tabel 3 G6 Optimal yaitu 83,33 hari dibanding menunjukkan bahwa rata-rata umur panen genotipe G1, G3, G4, G5, G7 dan G8.

Tabel 2. Rata-rata Anthesis Silking Interval (Hari) 8 Genotipe dan 2 Varietas Pembanding pada Kondisi Perlakuan Optimal, Cekaman Sedang dan Cekaman Parah.

\begin{tabular}{cccc}
\hline \hline \multirow{2}{*}{ Genotipe/Varietas } & \multicolumn{3}{c}{ Perlakuan } \\
\cline { 2 - 4 } & Optimal & Cekaman Sedang & Cekaman Parah \\
\hline \hline G1 & 2.00 & 2.00 & $2.00 \mathrm{~b}$ \\
G2 & 1.33 & 1.00 & 1.33 \\
G3 & 2.00 & $2.33 \mathrm{~b}$ & $2.00 \mathrm{~b}$ \\
G4 & 1.67 & 2.00 & $3.00 \mathrm{ab}$ \\
G5 & 1.67 & 1.00 & 1.00 \\
G6 & 2.00 & 1.67 & $3.00 \mathrm{ab}$ \\
G7 & 1.67 & $3.00 \mathrm{ab}$ & $2.33 \mathrm{~b}$ \\
G8 & 1.67 & 1.67 & $3.00 \mathrm{ab}$ \\
BIMA 3 & 1.67 & 2.00 & 2.00 \\
BIMA 7 & 2.00 & 1.67 & 1.33 \\
\hline \hline
\end{tabular}

NP.BNT taraf $0.05=0.63$

Keterangan : Nilai rata-rata pada kolom yang sama yang diikuti oleh huruf a berarti berbeda nyata dengan varietas Bima 3, huruf b berbeda nyata dengan varietas Bima 7 berdasarkan uji BNT taraf 0.05

Tabel 3. Rata-rata Umur Panen (Hari) 8 Genotipe dan 2 Varietas Pembandingpada Kondisi Perlakuan Optimal, Cekaman Sedang dan Cekaman Parah.

\begin{tabular}{cccc}
\hline \hline \multirow{2}{*}{ Genotipe/Varietas } & \multicolumn{3}{c}{ Perlakuan } \\
\cline { 2 - 4 } & Optimal & Cekaman Sedang & Cekaman Parah \\
\hline \hline G1 & $89.67 \mathrm{ab}$ & $91.00 \mathrm{ab}$ & $91.33 \mathrm{ab}$ \\
G2 & $83.33 \mathrm{a}$ & 87.67 & 87.67 \\
G3 & $84.67 \mathrm{~b}$ & $89.00 \mathrm{~b}$ & 89.00 \\
G4 & $90.00 \mathrm{ab}$ & $91.00 \mathrm{ab}$ & $91.33 \mathrm{ab}$ \\
G5 & $84.00 \mathrm{~b}$ & 87.00 & 88.33 \\
G6 & $83.33 \mathrm{a}$ & 87.00 & $89.33 \mathrm{~b}$ \\
G7 & $85.33 \mathrm{~b}$ & $89.00 \mathrm{~b}$ & 89.00 \\
G8 & $89.67 \mathrm{ab}$ & $90.67 \mathrm{ab}$ & $91.00 \mathrm{ab}$ \\
BIMA 3 & 85.00 & 87.67 & 88.33 \\
BIMA 7 & 82.33 & 87.00 & 87.67 \\
\hline \hline
\end{tabular}

NP.BNT taraf $0.05=1.47$

Keterangan : Nilai rata-rata pada kolom yang sama yang diikuti oleh huruf a berarti berbeda nyata dengan varietas Bima 3, huruf b berbeda nyata dengan varietas Bima 7 berdasarkan uji BNT taraf 0.05

\section{Panjang Akar}

Pada parameter panjang akar (Tabel

4), menunjukkan bahwa rata-rata panjang akar tertinggi terdapat pada genotipe G5

Cekaman Sedang yaitu 27,27 cm 
dibandingkan dengan genotipe dari G1, pembentukan bunga dan pengisian biji G2, G3, G4, G6, G7 dan G8.

Cekaman kekeringan yang diberikan bobot tongkol per petak (kg/petak) dan pada awal fase pembungaan sangat hasil per hektar (ton/ha). Menurut Roy berpengaruh pada umur munculnya bunga Efendi (2009), semakin tinggi nilai jantan dan betina serta interval muncul anthesis silking interval (ASI ) semakin keduanya (anthesis silking interval). Hal rendah hasil karena tidak terjadi ini dapat terjadi karena pada saat proses sinkronisasi pembungaaan. ASI negatif fotosisntesis, air sangat dibutuhkan untuk diartikan bahwa rambut terlebih dahulu metabolisme sel, pembentukan bahan dan siap diserbuki sebelum tersedia bunga energi untuk masuk pada fase reproduksi jantan.

Tabel 4. Rata-Rata Panjang Akar (Cm) 8 Genotipe dan 2 Varietas Pembanding pada Kondisi Perlakuan Optimal, Cekaman Sedang dan Cekaman Parah.

\begin{tabular}{clcc}
\hline \hline \multirow{2}{*}{ Genotipe/Varietas } & \multicolumn{3}{c}{ Perlakuan } \\
\cline { 2 - 4 } & \multicolumn{1}{c}{ Optimal } & Cekaman Sedang & Cekaman Parah \\
\hline \hline G1 & 22.51 & 15.66 & 19.43 \\
G2 & 20.30 & 15.53 & 18.71 \\
G3 & 23.07 & 18.65 & $23.95 \mathrm{a}$ \\
G4 & $24.96 \mathrm{a}$ & 18.38 & 17.40 \\
G5 & 22.11 & $27.27 \mathrm{a}$ & 18.93 \\
G6 & 21.09 & 18.19 & 17.71 \\
G7 & 21.31 & $23.17 \mathrm{a}$ & 19.05 \\
G8 & 20.76 & 19.21 & 20.24 \\
BIMA 3 & 20.01 & 17.45 & 17.69 \\
BIMA 7 & 24.09 & 25.37 & 25.78 \\
\hline
\end{tabular}

NP.BNT taraf $0.05=3.98$

Keterangan : Nilai rata-rata pada kolom yang sama yang diikuti oleh huruf $(a, b)$ berarti berbeda nyata dengan varietas Bima 3 , huruf $\mathrm{b}$ berbeda nyata dengan varietas Bima 7 berdasarkan uji BNT ta.raf 0.05

Fukai dan Croper, (1995) dalam kemampuan tanaman untuk menjaga Soepandie (2006), mengemukakan bahwa potensi jaringan dengan menekan genotipe yang toleran terhadap cekaman kehilangan air atau menurunkan potensial kekeringan mempunyai kemampuan airnya melalui akumulasi gula, asam genetik untuk mentolerir keadaan amino dan prolin. Selanjutnya Noggle dan lingkungan yang tercekam/kurang optimal Frizt (1983), menjelaskan bahwa fungsi melalui mekanisme adaptasi seperti air bagi tanaman yaitu : (1) sebagai 
senyawa utama pembentuk protoplasma,

(2) sebagai pelarut bagi masuknya mineral-mineral dari larutan tanah ke tanaman dan sebagai pelarut mineral nutrisi yang akan diangkut dari suatu bagian sel ke bagian sel yang lain, (3) sebagai media terjadinya reaksi-reaksi metabolik, (4) menjaga turgiditas sel dan berperan sebagai tenaga mekanik pembesaran sel. Dari peran tersebut, maka konsekuensi langsung atau tidak langsung bila air tidak cukup tersedia akan mempengaruhi semua proses metabolik tanaman, sehingga menurunkan pertumbuhan dan produksi tanaman.

Faktor lingkungan juga memberikan pengaruh terhadap umur panen, tanaman jagung dengan lingkungan yang mengalami cekaman air (Water Stress) akan mengalami percepatan dalam umur panen. Menurut Adriani et al (2015) Faktor lingkungan berkontribusi nyata terhadap penampilan hibrida silang puncak untuk karakter umur panen, panjang tongkol dan bobot 1.000 biji dalam kadar air 15\%. Hal lainnya terhadap pertumbuhan akar yaitu bahwa pada tanaman jagung yang mengalami cekaman kekeringan akan mengalami pertumbuhan akar yang panjang dan merupakan salah satu mekanisme ketahanan akar dalam merespon kondisi cekaman kekeringan. Menurut Roy Efendi dan Azrai (2010), Kemampuan meningkatkan luas perakaran pada kondisi cekaman kekeringan dengan cara meningkatkan panjang akar dan memperbanyak cabang akar merupakan kemampuan tanaman dalam memperluas jangkauan akar ke lapisan tanah yang lebih dalam dengan lengas tanah yang lebih besar dibanding di lapisan permukaan tanah, sehingga akar berpeluang besar mengabsorbsi air tanah lebih banyak.

\section{KESIMPULAN}

Keragaan genetik dari beberapa genotipe jagung toleran cekaman kekeringan pada berbagai tingkat pemberian air memperlihatkan keragaman;

Genotipe G7 adalah genotipe dengan tinggi tanaman yang tertinggi. Genotipe G2 dan G5 adalah genotipe yang mempunyai nilai anthesis silking interval (ASI) terendah dan umur panen tercepat, sementara G3 merupakan genotipe yang maempunyai akar terpanjang pada semua tingkat pemberian air. 


\section{DAFTAR PUSTAKA}

Aisyah, Siti S. 2014. Keragaan Genetik Galur Jagung Pada Kondisi Cekaman Kekeringan Dan Pemupukan Nitrogen Rendah Di Dua Lokasi. Tesis Program Pascasarjana Universitas Hasanuddin, Makassar.

Adriani A., M. Azrai, W. B. Suwarno, S.H. Sutjahjo. 2015. Pendugaan Keragaman Genetik Dan Heritabilitas Jagung Hibrida Silang Puncak Pada Perlakuan Cekaman Kekeringan. Informatika Pertanian, Vol. 24 No.1, Juni 2015 : 91 - 100.

Darnis. 2015.. Seleksi Dan Karakteristik Jagung Calon Hibrida Toleran Cekaman Kekeringan. Tesis Program Pasca Sarjana Magister Agroteknologi UMI, Makassar

Efendi, Roy. 2009. Metode dan Karakter Seleksi Toleransi Genotipe Jagung Terhadap Cekaman Kekeringan. Tesis Sekolah Pascasarjana Institut Pertanian Bogor.

Efendi, Roy dan M. Azrai. 2010. Tanggap Genotipe Jagung Terhadap Cekaman Kekeringan: Peranan Akar. Jurnal Penelitian Pertanian Tanaman Pangan Vol. 29 No. 1 2010.

M. Aqil, I.U. Firmansyah, dan M. Akil, 2007. Pengelolaan Air Tanaman Jagung. Balai Penelitian Tanaman Serealia, Maros.

Noggle GR, GJ Pritz. 1983. Introducttory Plant Physiology. Prentice hall, inc. Egglewood Cliffs. New Jersey 627p. Sopandie D. 2006. Perspektif Fisiologi Dalam Pengembangan Tanaman
Pangan di Lahan Marginal. Orasi Ilmiah Guru Besar Tetap Fisiologi Tanaman. Fakultas Pertanian, Institut Pertanian Bogor. 16 September 2006.

Subaedah, St. 2018. Agroteknologi Lahan Kering. Penerbit Nas Media Pustaka. Makassar 202p.

Subaedah, St., Nirwana, Suriyanti. 2014. Improvement of yield maize in dry land who experience drought stress with use of organic matter. Adv. Environ. Biol. 8:930-934.

Sutoro, Y. Sulaeman, dan Iskandar. 1988. Budidaya tanaman jagung. Dalam. Jagung. Subandi, Mahyudin Syam, Adiwidjono (Penyunting). Hal. 49 67. Puslitbangtan.

Shukla, N., R.P. Awasthi, L. Rawat, and J. Kumar. 2012. Biochemical and physiological responses of rice (Oryza sativa L.) as influenced by Trichoderma harzianum under drought stress. Plant Physiology and Biochemistry 54: 78-88.

Teguh Wijayanto, Candra Ginting, Dirvamena Boer dan Wa Ode Afu. 2014. Ketahanan Sumberdaya Genetik Jagung Sulawesi Tenggara Terhadap Cekaman Kekeringan Pada Berbagai Fase Vegetatif. JURNAL AGROTEKNOS Juli 2014 Vol. 4 No. 2. Hal 101-106 ISSN: 2087-7706.

Wahditiya, Andi Adriani. 2016. Analisis Genetik Dan Seleksi Hibrida Jagung Pada Kondisi Optimal Dan Suboptimal. Tesis Sekolah Pascasarjana Institut Pertanian Bogor. 